\title{
Sustainability, institutional arrangement and challenges of community based climate smart practices in northwest Ethiopia
}

Tsega Adego ${ }^{1 *}$, Belay Simane ${ }^{1}$ and Getachew Abebe Woldie ${ }^{2}$

\begin{abstract}
Background: Crop productivity in the highlands of Ethiopia is critically challenged by land degradation and climate change and variability. Massive plantations and several kilometers of soil and water conservation technologies have been practiced in response to those challenges. Yet land degradation and the level of sustainability of the technologies have continued to be critical challenges. Thus, the objective of this research was to examine the sustainability, challenges and future prospect of climate smart community-based soil and water conservation practices. Data were collected using household survey, key informant interview and focus group discussion. Analytic hierarchy process for multi-criteria decision making was used to analyze the sustainability of community-based climate smart practices.

Results: The finding revealed that the overall score of the sustainability dimensions was about $67.5 \%$, which lies in the zone of "sustained but at risk."The institutional arrangement has limitations in that farmers were involved in implementation phase while there is little room in planning, monitoring and evaluation phases. The major challenges of the soil and water conservation practices were: destruction of the communal forests and structures for personal benefits, overlapping work calendar with irrigation and off-farm works and structures wasted farmland.

Conclusions: The success of the structures from the perspective of officials is expressed in terms of the numbers of kilometers constructed and community participation. However, it overlooks how it reduces the problem of land degradation and challenge of climate change and variability. Thus, in order to sustain the structures, direct participation of farmers at all stages of the work is encouraged. The sustainability of structures can also be partly ensured if it generates benefit to the local community.
\end{abstract}

Keywords: Community mobilization, Sustainability, Soil and water conservation, Analytic Hierarchy Process, Rib Watershed

\footnotetext{
*Correspondence: tsegagrace2007@gmail.com

${ }^{1}$ Center for Environment and Development Studies, College

of Development Studies, Addis Ababa University, Addis Ababa, Ethiopia

Full list of author information is available at the end of the article
} 


\section{Background}

Ethiopia is one of the agrarian Sub-Saharan African countries dominated by subsistence small-scale farmers with less than 2 hectares of land [1]. Yet agriculture continues to be the most dominant sector, accounting for nearly $37 \%$ of gross domestic product (GDP), $73 \%$ of employment and $84 \%$ of foreign export earnings. The country's Growth and Transformation Plan I (GTP) that runs from 2010 to 2015 was over with average GDP growth of $10.9 \%$ [2]. GTP II is midway, and one of its strategic objectives is to ensure food security and broaden export base of the country which is expected to bring a long-term structural transformation to industry. This implies the success is determined by the productivity of smallholder farmers that account 95 percent of the national agricultural output [3]. However, agricultural productivity in the smallholder sector is constrained by climate change and variability, land degradation, traditional farming techniques and low level of investment in productivity enhancing technologies, inter alia [4-6]. As a result, large areas of the country are already experiencing food insecurity [7].

The highlands of Ethiopia are inhabited with dense population and highly vulnerable to land degradation. People look for fertile areas and create intense pressure on natural resources: water, soil and vegetation $[8,9]$. Research shows that land degradation has severely eroded $50 \%$ of the highlands of Ethiopia where it is reducing annual land productivity by $2.2 \%$ [10-12] and an annual soil loss of 42 ton/hectare (ha)/year was estimated across the country [13]. The long-term productivity loss due to soil erosion alone reduces annual agricultural GDP by up to $3 \%$ [1]. Thus, the livelihood of many millions of farmers is critically challenged. This degradation has been intensified by massive deforestation, unmanaged grazing and improper farming practices that has in turn resulted in production decline and disturbed ecology $[10,14]$.

Sustainable land and water management practices are commonly promoted in Africa that focus on tackling land degradation although they are equally criticized for less on communities' potential to adapt and cope to the effects of climate change $[15,16]$. From adaptation and mitigation point of view, soil and water conservation (SWC) practices are considered as climate smart due to the potential of rehabilitating the ecological environment, maximizing food production through conserving soil fertility, keeping moisture and controlling soil degradation [9].

In order to adapt climate challenges and rehabilitate degraded land, the government of Ethiopia has been intervening in many ways. Promotion of SWC technologies through community campaign is one of the key interventions. Various technologies were introduced and practiced since the 1980s, particularly on the northern Ethiopian highlands through food for work program in response to the famine occurred during that time $[13,17$, 18]. Many resources have been invested in many parts of Ethiopia, and several kilometers of community-based soil and water conservation measures were constructed on croplands [10]. Though the quantitative achievements were significant, the problem of land degradation has continued as critical challenge in the country in general and the study area (Rib watershed) in particular. This can be justified in various scenarios. Some reports indicated that the farmers' acceptance of these conservation structures is not well considered $[12,19]$ and as a result have not been sustainably used by farmers [20, 21]. Most soil and water conservation planning approaches rely on experts and hardly consider farmers' knowledge, role of agro-ecology and differences in spatial and temporal terms $[22,23]$. With the consideration of the competing reasons, there is a need to investigate the status of sustainability in un-researched areas. The previous researches have paucity to consider the communitybased projects. To the best of the researchers' knowledge, there are scant studies in the topic and in the study area. A closer work to this study is by Simane and Zaitchik [24] that investigates the sustainability of community-based adaptation projects in the Blue Nile Highlands of Ethiopia. However, our study has contribution in reducing the subjective ratings of dimensions, differ in number and type of dimensions and indicators. Thus, this research is aimed to analyze the sustainability of mass-mobilized SWC practices in the case of Rib watershed, Ethiopia. Moreover, it also examines the institutional arrangement, current challenges and prospects of the practices.

\section{Methods \\ Description of study area}

The study was conducted in northwest Ethiopia, Amhara Region, Rib watershed. It is located between $10^{\circ} 43^{\prime}$ and $11^{\circ} 53^{\prime} \mathrm{N}$ latitude and $37^{\circ} 47^{\prime} \mathrm{E}$ and $37^{\circ} 54^{\prime} \mathrm{E}$. It originates from Guna Mountain and finally joins Lake Tana [14]. It has a drainage area of about $1586 \mathrm{~km}^{2}$. The elevation of the Rib watershed ranges from 1676 to 4135 m.a.s.l. The landscape of the watershed is highly rugged with high mountain range on the south and closely dispersed hills and their escarpments in the central and northern parts of the watershed [25]. The river intersects Ebnat, Farta, Libo Kemkem and Fogera Woredas. ${ }^{1}$ Rib Dam is under construction since 2008. It has a reservoir storage capacity of 234 million $\mathrm{m}^{3}$. The area to be flooded to form the

\footnotetext{
${ }^{1}$ Next to region and zone, it is the third hierarchy of administrative structure in Ethiopia.
} 
Rib Reservoir is situated in Farta and Ebnat Woredas [26]. The source of drinking water in the watershed is deep wells, ponds and rivers.

Woina Dega (Subtropical zone) and Dega (cool zone) are the dominant traditional agro-climate zones of the watershed. Dega traditional climate zone has an average temperature about $16{ }^{\circ} \mathrm{C}$ and an annual rainfall between 1200 and $2200 \mathrm{~mm}$ with elevation between 2300 to $3200 \mathrm{~m}$. Woina Dega average temperature is $22{ }^{\circ} \mathrm{C}$, the annual rainfall is between 800 and $1200 \mathrm{~mm}$, and the average elevation ranges between 1500 to $2500 \mathrm{~m}$ [27]. June, July, August and September are the rainy seasons. The peak flow occurs in August with monthly average flow of about $52 \mathrm{~m}^{3} / \mathrm{s}$ [28]. The percentage share of the land cover in Rib watershed for agriculture, agro-pastoral, pastoral, silviculture and urban is, respectively, 62, 24, $14,0.6$ and $0.18 \%$. The potential of the area in terms of land use is cultivation $85.7 \%$, grassland, afro alpine $1.5 \%$, shrub land $0.21 \%$ and others $0.06 \%$. The land allocated for plantation was marginal with a percentage share of $0.6 \%$ [29].

\section{Data source and collection methods Primary data collection}

Primary data were collected through household survey questionnaire, key informant interview and focus group discussion.

\section{A. Household survey questionnaire}

Household survey questionnaire was the heart of the data collection process. It was devised for collecting the quantitative data, and it was also used to gather some supplementary open-ended information. The questionnaire was designed to gather information about the household demographic and social characteristics, community participation, institutional arrangement, importance, achievement, challenges and sustainability of community-based soil and water conservation (CBSWC). The questionnaire was filled through interviewing the heads of farm households for the fact that most of them cannot read, write and understand the questions. Data collectors were recruited and given a day long training to introduce the objective and format of the questionnaire.

\section{B. Key informant interview}

Face-to-face key informant interview was held with experts and officials. Three expertises from the three woredas, two from the zone office of agriculture and rural development and nine development agents ${ }^{2}$ from kebeles were interviewed. The interview was focused on the achievements, gaps and sustainability of the mass-mobilized conservation works. Moreover, kebele ${ }^{3}$ crop extension agent and the kebele natural resource development leaders within each agro-ecosystem (Fogera plain and Libo-Farta highlands) provided the specific village-level challenges and achievements of the structure works.

\section{Focus group discussion}

The survey questionnaire output was triangulated with focus group discussion (FGD) that was conducted in each of the agro-ecosystem. Five focus group discussion groups with farmers and one with development agents was conducted. Participants shared their experience about the response and sustainability of communitymobilized SWC activities within their village. How the SWC activities permit participation of the farmers' in the decision making process from its planning to evaluation phase was fundamental issue. The sustainability of this natural resource management depends on the acceptance of the farming community. As a result, the community's participation modality of being whether voluntarily or forced was also addressed. Moreover, investigating if the farming community is really benefiting from such practices is another concern. The other FGD consists of development agents (DAs) who principally determine the weight of sustainability dimensions. The discussion was moderated by the researcher though pre-developed interview guides. All people's ideas and experiences were properly entertained through managing individual dominancy.

\section{Secondary data collection}

Sustainability analysis of SWC practices utilized the local woreda-level reports. Moreover, books, journal publications and magazines played a central role in this research. Precautions were taken to ensure that whether the data had achieved the characteristics of reliability, suitability and adequacy. The suitability of the data was scrutinized through checking whether it was collected by appropriate methods, its scope, authenticity, units of measurement, analysis, etc.

\section{Sample size}

This research follows multistage sampling. Firstly, Rib watershed was stratified into Dega and Woina Dega

\footnotetext{
2 These are experts employed by the government that are diploma $(10+3)$ or degree (BA) holders.

${ }^{3}$ Kebele is the lowest administrative structure of Ethiopia.
} 
Table 1 Proportional sample size distribution. Source: Computed from [30]

\begin{tabular}{|c|c|c|c|c|}
\hline Climatic zone & Number of Kebeles & $\begin{array}{l}\text { Total household size } \\
\text { by } 2014\end{array}$ & Sampled Kebeles & $\begin{array}{l}\text { Proportional } \\
\text { sample size }\end{array}$ \\
\hline Dega & 11 & 15,278 & Ata Sahrna & 73 \\
\hline Woina Dega & 40 & 65,435 & $\begin{array}{l}\text { Woji; Tiwha;Kokit; Agela; Tara; Bura; Angot; } \\
\text { Yifag; Hiruy; Tsegur }\end{array}$ & 310 \\
\hline
\end{tabular}

traditional climate zones. Then, within each zone, Kebeles were randomly selected. The sample size was determined proportional to population size of each climate zone. The complete list of the farm households was available in the Kebele administration. Then, the sampling unit households were selected through systematic random sampling with sampling interval (k). The first unit that was used as a starting point of the interval was identified through simple random sampling. According to [31], the representative sample size from finite population can be determined through the following formula (Table 1):

$$
n=\frac{z^{2} \cdot p \cdot q \cdot N}{e^{2}(N-1)+z^{2} \cdot p \cdot q}
$$

where $n=$ size of sample, $N=$ total households which is 80,713 (household size within the selected Kebeles of the sub-basin), $p^{4}=$ sample proportion, $q=1-p$, which is equal to $0.5, z=1.96$ at $95 \%$ (the value of the standard variate as per the table of area under normal curve for the given confidence level for this case of 99\%),

Therefore, the sample size is determined to be:

$$
n=\frac{1.96^{2} \cdot(0.5)(0.5) \cdot(80713)}{0.05^{2}(80713-1)+1.96^{2} \cdot(0.5) \cdot(0.5)}=\frac{77516.8}{202.7}=383
$$

\section{Method of data analysis}

Multi-criteria decision making (MCDM) is a world of concepts, approaches, models and methods to help the decision makers to describe, evaluate, sort, rank, select or reject issues on the basis of evaluation criteria [32]. The weighted sum model, the analytic hierarchy process, analytical network process, the weighted product model, preference ranking organization method for enrichment evaluations, the elimination and choice expressing reality and the order preference by similarity to ideal solution MCDM methods are used widely. However, it is impossible to precisely determine the best MCDM method [33]. The analytic hierarchy process (AHP) has become increasingly popular that was modified by Belton and

\footnotetext{
${ }^{4}$ To estimate $p$, one method may be to take the value of $p=0.5$ in which case ' $n$ ' will be the maximum and the sample will yield at least the desired precision. The other method may be to take an initial estimate of $\mathrm{p}$, which either may be based on personal experience judgment or may be the result of a pilot study.
}

Gear [34]. As compared to other multi-criteria decision making criteria's, AHP/ANP is not complicated, having the power of mixing qualitative and quantitative factors, and possible to arrange factors hierarchically [35]. As a result, the sustainability of CBSWC practices was analyzed through analytic hierarchy process (AHP) for multi-criteria decision making adapted from Simane and Zaitchik [24] that was originally developed by Saaty [36]. This method is well suited for situations where criterions can be organized into a hierarchy by dividing the problem characteristics into sub-criteria (indicators). The stages involved in analytical hierarchy process method are presented as follows:

\section{Step 1: Goal and criteria definition}

The first level of the hierarchy was defined by the overall objective of CBSWC, as an adaptation option is to reverse the natural resource degradation, conserve the ecosystem and increasing productivity. The second level is the social, institutional, economic, technical and environmental dimensions of sustainability. These dimensions with the respective indicators are determined with the existing literature $[37,38]$. These indicators were collected from the literature and were commented by the expert group. The indicators of respective dimensions are presented in "Analytic hierarchal process: sustainabilityof community-based soil and water conservation practices" section.

\section{Step 2: Weight assignment}

The weight of each dimension was determined through participating DAs experts, and the consideration of the existing literature of pairwise comparison matrix. The judgment of experts with the respective numerical ratings was: equally preferred (1), moderately preferred (3), strongly preferred (5), very strongly preferred (7) and extremely preferred (9) where 2,4 and 6 were intermediate values. The higher the weights of the dimension, the higher the importance for reversing the natural resource degradation, conserve the ecosystem and increasing yield. Suppose the comparison of dimension $i$ with $j$ be represented by $a_{i j}$, then the pairwise comparison matrix formulated by experts $[\mathrm{C}]$ is given as: 


$$
[C]=\left|\begin{array}{cccc}
1 & a_{12} & \ldots & a_{1 \mathrm{n}} \\
1 / a_{12} & 1 & \ldots & a_{2 \mathrm{n}} \\
\vdots & \vdots & \ddots & \vdots \\
1 / a_{1 \mathrm{n}} & 1 / a_{2 \mathrm{n}} & \cdots & 1
\end{array}\right|
$$

Note that we have reciprocal values across the diagonal, since we are simply inverting the ratio. Furthermore, we have all ones down the diagonal since comparing an alternative to itself would result in a ratio of $1: 1$. Suppose that the sum of the first column $1+1 / a_{11}+\cdots+1 / a_{1 \mathrm{n}}$ be denoted by S1, and Sn denotes the sum of column $n$, then the standardized matrix was formulated as:

$$
=\left|\begin{array}{llll}
1 / S_{1} & a_{12 /} / S_{2} & \cdots & a_{1 \mathrm{n}} / S_{\mathrm{n}} \\
\left(1 / a_{12)} / S_{1}\right. & 1 / S_{2} & \cdots & a_{2 \mathrm{n}} / S_{\mathrm{n}} \\
\vdots & \vdots & \ddots & \vdots \\
\left(1 / a_{1 \mathrm{n}}\right) / S_{1} & \left(1 / a_{2 \mathrm{n})} / S_{2}\right. & \cdots & 1 / S_{\mathrm{n}}
\end{array}\right|
$$

The weight of the overall dimensions is calculated by averaging respective rows and is denoted as follows:

$$
\{W\}=\left|\begin{array}{c}
w_{1} \\
w_{2} \\
\vdots \\
w_{\mathrm{n}}
\end{array}\right|
$$

Step 3: Consistency ratio

The consistency is determined though the following procedures. Firstly, determine the weight sums vector $\left(W_{\mathrm{s}}\right)=[\mathrm{C}] .\{\mathrm{W}\}$.

$$
\mathrm{W}_{\mathrm{s}}=\left|\begin{array}{llll}
1 & a_{12} & \ldots & a_{1 \mathrm{n}} \\
1 / a_{12} & 1 & \ldots & a_{2 \mathrm{n}} \\
\vdots & \vdots & \ddots & \vdots \\
1 / a_{1 \mathrm{n}} & 1 / a_{2 n} & \ldots & 1
\end{array}\right| \cdot\left|\begin{array}{c}
w_{1} \\
w_{2} \\
\vdots \\
w_{\mathrm{n}}
\end{array}\right|
$$

Secondly, find the consistency vector with a dot product, i.e., consistency $=\left\{W_{s}\right\} .\{1 / W\}$ and then determine the average of the elements of consistency that can be assigned as $\lambda$. The consistency index is determined as:

$$
C I=\frac{(\lambda-n)}{n-1}
$$

where $n$ is the number of criteria dimensions. As proposed by Saaty [39], consistency ratio (CR) is the ratio of consistency index and random consistency index (RI), i.e.,

$$
\mathrm{CR}=\frac{\mathrm{CI}}{\mathrm{RI}}
$$

$\mathrm{RI}$ is the average CI of 500 randomly filled in random-like matrix. Various authors have computed and obtained different RIs depending on the simulation method and the number of generated matrices [40]. Saaty [38] provides the calculated RI value for matrices of different sizes. The average random consistency index is referred from a table. If the value of consistency ratio is smaller or equal to $10 \%$, the inconsistency is acceptable. Alternately, if the consistency ratio is greater than $10 \%$, the subjective judgment should be revised. The consistency ratio is found 9.19\%, which is acceptable.

Step 4: Rating and weighing the dimension indicators

The indicators were rated by households from a fivepoint scale of strongly agree to strongly disagree. The level of sustainability of each dimension is the ratio of the averaged weighted score to the weight of the dimensions (W). Then, the overall sustainability of CBSWC was calculated by averaging weighted rates of the five sustainability dimensions. Thus, the overall sustainability as presented in various literatures $[24,41]$ is determined as:

- Sustained: if the overall score is $\geq 70 \%$ and at least $70 \%$ score of each dimension

- Sustained but at risk: if the overall score is $\geq 50 \%$ and it does not matter if some dimensions might be below $50 \%$

- Unsustained: if the overall score is $<50 \%$

\section{Results and discussion} Household characteristics

This section presents the characteristics of farm households. About $80 \%$ of sampled farmers are married, $5 \%$ not married, $8.6 \%$ divorced and $6.8 \%$ widowed. Majority of the respondents (98.7\%) are Orthodox Christians, while the remaining (1.3\%) are Muslims. The average household size is 5.28 with standard deviation of 1.87 . The education level of households shows $38.7 \%$ illiterate, $53.5 \%$ read and write and $7.8 \%$ primary and above completes. The average age and farm experience is, respectively, 46.8 and 29.2 years with respective standard deviation of 11.31 and 12.46. About $14 \%$ of respondents did not have own land. These households use various alternatives of renting $(41.8 \%)$, crop sharing (47.3\%), temporary gift from relatives and friends (41.8\%) and other options (5.5\%). A farmer may use one or more of the aforementioned strategies for growing crops. The key informant experts' 
Table 2 Pairwise comparison of sustainability dimensions

\begin{tabular}{|c|c|c|c|c|c|}
\hline & Social & Institutional & Technical & Economic & Environmenta \\
\hline Social & 1.00 & 0.50 & 0.33 & 1.00 & 0.50 \\
\hline Institutional & 2.00 & 1.00 & 0.50 & 1.00 & 0.50 \\
\hline Technical & 3.00 & 2.00 & 1.00 & 2.00 & 3.00 \\
\hline Economic & 1.00 & 1.00 & 0.50 & 1.00 & 3.00 \\
\hline Environmental & 2.00 & 2.00 & 0.33 & 0.30 & 1.00 \\
\hline Sum & 9.00 & 6.50 & 2.66 & 5.30 & 8.00 \\
\hline
\end{tabular}

Table 3 Standardized matrix for calculating weight and score of the dimensions

\begin{tabular}{|c|c|c|c|c|c|c|c|c|c|}
\hline Dimension & Social & Institutional & Technical & Economic & Environmental & Sum & Weight & $\begin{array}{l}\text { Rated } \\
\text { with indicators }\end{array}$ & $\begin{array}{l}\text { Weighted \% } \\
\text { score }\end{array}$ \\
\hline Social & 0.11 & 0.08 & 0.12 & 0.19 & 0.06 & 0.56 & 0.11 & 0.0718 & 65.27 \\
\hline Institutional & 0.22 & 0.15 & 0.19 & 0.19 & 0.06 & 0.82 & 0.16 & 0.1159 & 68.18 \\
\hline Technical & 0.33 & 0.31 & 0.38 & 0.38 & 0.38 & 1.77 & 0.35 & 0.2349 & 67.11 \\
\hline Economic & 0.11 & 0.15 & 0.19 & 0.19 & 0.38 & 1.02 & 0.20 & 0.1514 & 75.7 \\
\hline Environment & 0.22 & 0.31 & 0.12 & 0.06 & 0.13 & 0.84 & 0.17 & 0.104 & 61.18 \\
\hline Sum & 1.00 & 1.00 & 1.00 & 1.00 & 1.00 & 5.00 & 1 & & 67.48 \\
\hline
\end{tabular}

level of education is diploma and bachelors with average experience of six years. Because of the Kebele-level road projects, most villages are partially accessible for three wheel and motorcycles. The average time in minutes to the nearest market, farm and main road is $47.47,21.44$ and 12.72 , respectively, with respective standard deviation of $31.85,13.41$ and 12.47 .

\section{Analytic hierarchal process: sustainability}

of community-based soil and water conservation practices SWC works had been implemented in different modalities. The first is on the land under public utility where it happened in public path ways, water ways and waste lands. The second is on common property resources such as area closures and wood lands. The third option is on individual farmland [42]. This study is delimited to the second and third options. There are commonly practiced biological and mechanical SWC works in the study area. This study is delimited to soil bund terracing, stone bund terracing, check dam and trees planted for hillside closure. The degree of sustainability of these structures is quantitatively measured through driving the analytic hierarchal process with five dimensions (Table 2).

Following this standard procedure, the overall score of the dimensions as presented in Table 3 is found to be $67.48 \%$ which lies in the zone of "sustained but at risk." Disentangled sustainability dimension scores portray that social $65.25 \%$, institutional $68.2 \%$, technical $67.1 \%$, economic $75.72 \%$ and environmental $61.2 \%$. Thus, only the economic dimension falls in the sustained category.
The detail for each dimension with respective indicators is explained as follows.

\section{a. Social sustainability}

The weight of the social dimension with the judgment of the development agent experts is 0.11 . The indexed dimension average is $65.25 \%$ where it falls in the range of sustained but at risk. One of the key indicators for measuring the social sustainability is whether the farmers had training or not. Farmers had rated all indicators from strong agreement to strong disagreement. About $65,21,8$ and $6 \%$ of the farmers, respectively, rated the provision of SWC training as neutral, strongly disagree, agree and disagree.

Locally contextualized plan is crucial indicator for sustaining SWC. The failure of conservation programs partly emerges from planners and implementing agencies ignorance of sociocultural factors as key determinants of the success or failure of conservation programs [19]. To be sustainable, participants must support and encourage practices and not create pressure that undermines them [43]. However, about $32 \%$ of farmers agree on the unavailability of implementable plan for their specific village. The other $55 \%$ have neutral stand on the availability of local-level CBSWC action plan. Having a plan is a mere paper, and the key issue is whether it has permitted the participation of stakeholders. About $49 \%$ of farmers' believed that there was no equal involvement of individuals in the planning stage. About 
Table 4 Social and institutional sustainability dimension

\begin{tabular}{|c|c|c|c|c|c|c|c|c|}
\hline Dimension & Weight & Indicators & Scored & Total & $\%$ & Weight & Indexed & Dimension \% \\
\hline \multirow[t]{4}{*}{ Social } & \multirow[t]{4}{*}{0.11} & There is appropriate training of local communities & 1354 & 1915 & 0.707 & 0.0275 & 0.0194 & \multirow[t]{4}{*}{$(0.0718 / .011)^{*} 100=65.25$} \\
\hline & & $\begin{array}{l}\text { There is appropriate locally contextualized CBSWC } \\
\text { action plan }\end{array}$ & 1368 & 1915 & 0.714 & 0.0275 & 0.0196 & \\
\hline & & $\begin{array}{l}\text { There is equal involvement of farmers in the planning } \\
\text { stage }\end{array}$ & 1166 & 1915 & 0.609 & 0.0275 & 0.0167 & \\
\hline & & There is no free-rider & 1110 & 1915 & 0.58 & 0.0275 & 0.0160 & \\
\hline \multirow[t]{3}{*}{ Institutional } & \multirow[t]{3}{*}{0.17} & There is supervision by experts & 1404 & 1915 & 0.73 & 0.056 & 0.0409 & \multirow[t]{3}{*}{$(0.1159 / .17)^{*} 100=68.17$} \\
\hline & & There is participatory evaluation of CBSWC & 1303 & 1915 & 0.68 & 0.057 & 0.0388 & \\
\hline & & There is effective implementation of laws for CBSWC & 1218 & 1915 & 0.64 & 0.057 & 0.0363 & \\
\hline
\end{tabular}

Table 5 Technical and economic sustainability

\begin{tabular}{|c|c|c|c|c|c|c|c|c|}
\hline Dimension & Weight & Indicators & Scored & Expected (total) & $\%$ & Weight & Rated & Dimension \% \\
\hline \multirow[t]{3}{*}{ Technical } & 0.35 & $\begin{array}{l}\text { The SWC practices constructed with proper } \\
\text { spacing and arrangement }\end{array}$ & 1369 & 1915 & 0.663 & 0.117 & 0.0776 & $(.2349 / .35)^{*} 100=67.1 \%$ \\
\hline & & Easy for construction and suitable for plowing & 1302 & 1915 & 0.68 & 0.117 & 0.0796 & \\
\hline & & $\begin{array}{l}\text { The structures are good fits for the local } \\
\text { topography }\end{array}$ & 1282 & 1915 & 0.67 & 0.116 & 0.0777 & \\
\hline \multirow[t]{3}{*}{ Economic } & 0.2 & $\begin{array}{l}\text { It has created alternative income source for } \\
\text { the community }\end{array}$ & 1429 & 1915 & 0.746 & 0.067 & 0.0500 & $(0.1514 / 0.2)^{*} 100=75.72$ \\
\hline & & $\begin{array}{l}\text { The SWC practices do not waste the faming } \\
\text { land }\end{array}$ & 1428 & 1915 & 0.746 & 0.067 & 0.0500 & \\
\hline & & It has contribution for increasing crop yield & 1494 & 1915 & 0.78 & 0.066 & 0.0515 & \\
\hline
\end{tabular}

$56 \%$ reported the existence of free-rider farmers in the mobilization work. The FGD and DAs also indicated the problem where considerable number of farmers request permission presenting medical case and landlessness as major reasons.

\section{b. Institutional sustainability}

The institutional dimension is evaluated with the indicators of supervision issues, participatory evaluation and implementation. The dimension average falls on the range of sustained but at risk. The work of the structures from the beginning to the end requires the support of DAs. About 35\% of the farmers disagree on the presence of regular supervision. After the completion of the structures, the evaluation is usually made through selected heads of the village watersheds, without the involvement of all the ordinary farmers. In this regard, 32\% of respondents indicated their disagreement on the existence of participatory evaluation of CBSWC, while the remaining 35\% were neutral and $34 \%$ agreed on the presence of participation (Table 4).

The implementation of CBSWC has rules prepared by the respective watersheds. Among others, the rule commonly mentions the time management, administration of the structures and protected areas, material and labor contribution, etc. About $46 \%$ of farmers mentioned the lack of effective enforcement of these rules. Haphazardly, penalties are introduced on some late comers and absentees.' The penalty is usually made in the form of working more hours on the structures. [44] indicated that interventions would not be effective if farmers were not enthusiastic enough in widely accepting and maintaining the soil conservation structures.

\section{c. Technical sustainability}

The topography of the study area is completely diversified with the presence of hills, mountains, flat and swampy plains and gorges. These topographies require compatible structures. Farmers had evaluated the CBSWC with the indicators (see Table 5) of proper spacing, alignment of the structures such as stone/soil/plantation and whether the structures are good fits for the local topography. DAs provide training about the technical requirements of the structures. About one-fourth (27\%) of the respondents believed that the SWC spacing 
Table 6 Environmental sustainability

\begin{tabular}{|c|c|c|c|c|c|c|c|c|}
\hline Dimension & Weight & Indicators & Scored & Expected (total) & Rated & Weight & Weighted \% & Dimension average $\%$ \\
\hline \multirow[t]{4}{*}{ Environmental } & 0.17 & $\begin{array}{l}\text { The binding rules for the manage- } \\
\text { ment of conserved resources } \\
\text { properly implemented }\end{array}$ & 1241 & 1915 & 0.648 & 0.056 & 0.0363 & $(0.104 / .17)^{*} 100=61.18$ \\
\hline & & $\begin{array}{l}\text { The forest and other structures are } \\
\text { well maintained/preserved }\end{array}$ & 1166 & 1915 & 0.609 & 0.057 & 0.0347 & \\
\hline & & $\begin{array}{l}\text { Structures enrich biodiversity such } \\
\text { as in stream flow, fodder, etc. }\end{array}$ & 1109 & 1915 & 0.579 & 0.057 & 0.0330 & \\
\hline & & Structures reduce soil erosion & 1282 & 1915 & 0.67 & 0.056 & 0.037 & \\
\hline
\end{tabular}

was not suitable for plowing, while $63 \%$ agreed that it did not have serious challenge during cultivation.

Famers are key experts for evaluating the structures as they had indigenous knowledge developed across generation. About $35 \%$ of the respondents jugged that the structures that are being constructed in their area are good fits for the local topography while $45 \%$ disagree and the remaining $20 \%$ had neutral observation mentioning that they do not have critical observation on the issue. This implies that about half of the farmers did not trust the technical specification of the structures in their village. According to FGD of farmers, the mass campaign compromises quality as the usual target of DAs was to cover large area in short time.

\section{d. Economic sustainability}

Apart from enhancing productivity and preserving the environment, the direction of the government is to create employment opportunity for youths from communally protected areas. More than half of the respondents (56\%) reported that the protected areas had moderately created income source for the local community. The remaining $19 \%$ favor it and believed that it had improved the life of the community. This is exemplified through beekeeping for organized youths, fodder, stream flow, etc. Whereas let alone improving income, $24 \%$ of respondents reported that it did not brought any change on the community. This was also manifested through limiting the movement of their livestock to the former communal grazing lands, the regular labor required to work and maintain the structure.

The structural works are constructed both on communal and the individual farmers' land. Farmers have different views on the link between structures and farm land. Fifty-seven percentage of the respondents experienced that the SWC practices do not waste farmland, while $24 \%$ had reported the incompatibility of the structures and their farming practice. FGD discussants also reported that it wasted their land, brought insects, reptile and rats that cut and harmed the crop. The remaining are neutral on the effect of structures on farm land. Farmers were also asked if the construction of the structures brought benefit in terms of crop yield. Studies show that farmers have a reputation for being innovators and experimenters, willing to adopt new practices when they perceive some benefit will be gained [43]. About 58\% reported that the degraded land had recovered as a result of the structures and had boosted crop production. About 18\% of respondents observed no change on the yield, while the remaining reported that it had worsened the yield as it has competed the farmland. Thus, majority of the farmers are benefiting in terms of yield enhancement.

\section{e. Environmental sustainability}

Apart from soil and stone structures, plantation is one of the other activities under the CBSWC. The sustainability can be ensured if the agreed management rules are fully implemented. About $50 \%$ of respondents reported that there are set and implemented rules for the management of conserved resources, while $20 \%$ do not know the presence of these rules. The remaining 30\% reported the absence of binding rules where farmers are destructing the communal forests and structures for personal benefits. As a result, forests are not well preserved and protected (Table 6).

With the participation of the community, guards were employed to protect unauthorized plowing, cutting of trees, grass and grazing. If that happens, the guard immediately reports to the village members and Kebele administrator for action. These village committee members are responsible to distribute grass to the community through revolving lottery system. About half (42\%) of the respondents disagree that the set rules are properly implemented. FGD discussants as well as $43 \%$ of respondent farmers indicated the significant improvement in the stream flow, fodder biodiversity as a result of closures, while the remaining respondents (57\%) replied that the structures did not contribute for enriching biodiversity. 


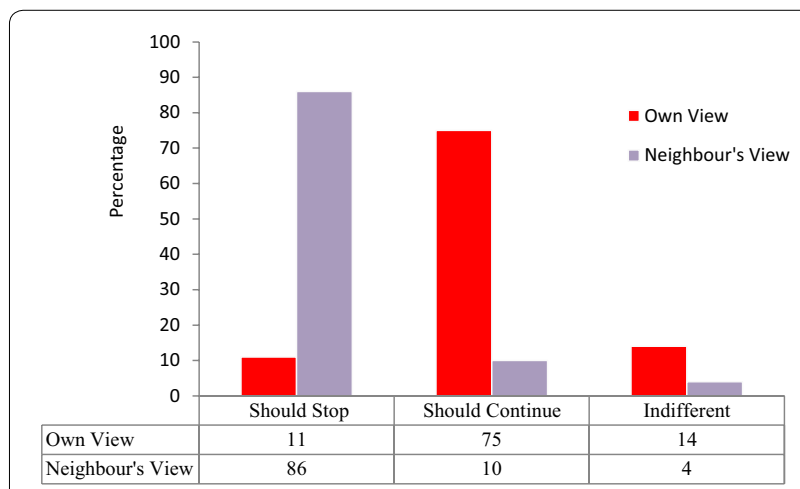

Fig. 1 Option on the future of CBSWC practices. It shows the inconsistent report on the future prospect of CBSWC

Discussants added that the problem with the structures was the lack of regular maintenance.

\section{Reflections on the importance and prospect of community-based soil and water conservations}

Although all ethical considerations were in place during data collection, farmers might not completely reflect their real observations and feeling in evaluative questions. In such cases, it is important to have triangulation questions. Farmers were asked their opinion on the future prospect of CBSWC. About 75\% reported that it is good and has to continue, and 11\% decide that it is weak and has to stop, while the remaining $14 \%$ are indifferent. The same question was presented to farmers to report how most of their neighbors perceive the future of CBSWC. The question is "How do most of your neighbors evaluate community-based soil and water conservation practices such as soil and stone bund construction, hillside terracing, and plantation in terms of its benefit and importance for their farming?" Surprisingly, the above figure was completely reversed. As shown in Fig. 1, about $86 \%$ of their neighbors feel that CBSWC could have to be stopped and $10 \%$ should have to continue, while the remaining $4 \%$ of their neighbors are indifferent on the importance of the structures. This was clarified through FGD where majority complain as the benefit they gain, and their invested labor and time are not compatible. Rather, they prefer to invest on their own land. Moreover, they complained that the communal structures are not properly kept while those energetic and thieves are destructing during night times for personal benefit.

\section{Institutional arrangement of community-based soil and water conservation works}

CBWSC is one of the national agendas that goes from the federal level down to the Kebles and villages. At federal level, Ministry of Agriculture and Natural Resource, and
Ministry of Environment, Forest and Climate Change activate the CBSWC. In line with this, Amhara regional state offices of Agriculture and Environmental protection had designed community mobilization at watershed level. A given watershed might intersect several politically delineated Woreda administration boundaries. Respective Woreda administrations organize their farming community into microwatersheds. These microwatersheds are further reorganized at Kebele and then finally at village level. Thus, the final implementable CBSWC is organized as 1 to 5 networking at village level, named as "development units." The organizational structure is largely criticized for being manipulated by the ruling party to achieve its political goal. The village-level watersheds had to elect and form their own committee structure consisting of secretary, surveyor and discipline committee. The surveyor had to take training through the arrangement of Kebele DAs. It is important to recall that in each Kebele administration, there are DAs of various expertise. One among them is coordinator and the others are specialists of crop and agricultural input, natural resource conservationist and veterinary specialists. The highest responsibility to manage and supervise falls on these DAs.

The community mobilization has its own annual calendar announced by the office of agriculture at zone and region level. Initially, ceremonial events are prepared by zone-level command post that comprises Kebele managers, Kebele administrators and some selected farmers and the Woreda command post. This event is responsible to evaluate the previous year weakness and strength and settle the future direction of the work. Then, the Woreda cascades its plan and implement at Kebele level usually from January 9 to March 9 for 60 days. This is a period where farmers are thought to be idle from their farming activity. However, the FGD discussants had reservation on this calender as this time had high opportunity cost, that it wastes their time that could have been used for irrigation works.

Key informants at Woreda reported that quality is ensured through quality assurance committee that includes DA and selected farmers. This committee controls the quality of the structures and handed over to the watershed farming community. The community selects guards for the enclosures protection. Those structures built on individual farmers land had been transferred to owner of the farm with a formal signed environmental protection form. However, there is lack of regular followup after transfer.

\section{Community participation}

The participation of the community is important in planning, implementation, monitoring and evaluation. 
The key issue is voluntary participation of farmers for providing their time, money and labor [45]. The direction of the government is voluntary participation of farmers. However, except a health problem and age retirement, practically it is mandatory for all farmers to participate on the CBSWC. In the discussion, farmers report the presence of some reluctant, free-rider and inconsistent participation among farmers. A quarter of farmers $(22 \%)$ replied that they did not participate in the CBSWC whereas $78 \%$ had been involved in the CBSWC. The other scenario is whether the massmobilized community had built on individual farm land. 57 and $43 \%$ of the farmers, respectively, replied that CBSWC had and had not been built on their land. 10,76 and $14 \%$ of those farmers who had been participating in the CBSWC had rated the quality of the structures as weak, good and excellent, respectively. This is partly justified with the rush work aimed for area coverage.

The FGD participant farmers outlined that they were fully involved in implementation phase while they rarely participate in the center planning, monitoring and evaluation phases. The problem of low participation in decision partially emanates due to DA and Woreda office of agriculture officials plan and decide with few selected farmers. They simply inform the decision for the mass farmer where there is narrow room for considering their opinions and comments. The study of [46] in south Ethiopia concluded that most of the SWC practices were not effective as a result of lack of participation of the community from planning to implementation, lack of community belonging to manage resources, inappropriate application of technologies and weak coordination among stakeholders. The finding reveals that the farming communities strongly work when the task comes from higher officials. Aligning with this study, the same experience was reported in Dogua Tenben Woreda [47] where the village community waits for task assignments from the higher levels; otherwise, the community did not act and thus tasks and programs lack longevity and continuity. But community participation should not be a flash in the span that flickers and vanishes [48]. DAs verified that a number of farmers request permission to be exempted from community work and sometimes send their children in place of them. The problem with this is children are too young and cannot afford to work as of their parents and is also legally unacceptable. Farmer discussants added that too many numbers of working days have competed their engagement in the off-farm works. The low level of income triggered by small and fragmented land induces farmers to work on income generating activities. Some are offended as
Table 7 Structural works from 2011 to 2015. Source: Computed from [52]

\begin{tabular}{lccc}
\hline Type of structure & Five year plan & Achievement & $\%$ \\
\hline Crop land terracing $(\mathrm{km})$ & 377,061 & 368,062 & 97.6 \\
Hillside Terracing $(\mathrm{km})$ & 85,207 & 53,744 & 63.1 \\
Check dam $(\mathrm{km})$ & 10,776 & 6748 & 62.6 \\
$\begin{array}{ll}\text { Closure of degraded land } \\
\quad \text { for restoration ha }\end{array}$ & 210,367 & 194,570 & 92.5 \\
\hline
\end{tabular}

they are obliged to work conservation works in others farm lands while they are landless. The landless youths are not direct beneficiaries of the conservation works. The degree of volunteer participation is also evidenced by [49] that found $76 \%$ of the respondents participated in SWC works by own interest in Arsi, Ethiopia. The same experience had happened in Laelay Maichew Woreda of Tigray regional state [50] where farmers thought that the conservation works on individual farm land could be left to individual farmers. Otherwise, all farmers, except old aged and sick persons, participate in the conservation work.

\section{Achievement and challenges of community-based soil and water conservation practices}

The participation of the community depends on the expected derived benefit in terms of yield, water supply and animal fodder [51]. FGD participant farmers had reported the increment of soil fertility and of yield from time to time. Though it is not allowed to collect wood in a communal land, the degraded areas had started to grow bushes and have potential to curb fuel wood challenges. Woredas' have limited data about structures mainly due to budgetary and institutional constraints. As presented in the report of [52], degraded area covered by useful plants in 2011 was $55,593 \mathrm{Ha}$ and by 2015 increased to 71,758 with the plantation of 943.28 million seedlings. This had increased the forest cover of the zone from 4.81 to $8.8 \%$. Thus, the presence of community-mobilized development of land using seedlings and structures had improved the forest cover and minimized the depletion of the natural resources (Table 7).

As shown in Fig. 2, the decreasing trend of the construction of new SWC was due to the increasing coverage of the structures across time. Given these achievements, various constraints were identified. The administrative direction of the government gave more attention on the structures. However, livestock management, maintenance and protection of plantation on communal land got minor attention. The structures are frequently broken by livestock, and farmers fail to regularly maintain it. For the fact that SWC need the individual and collective 


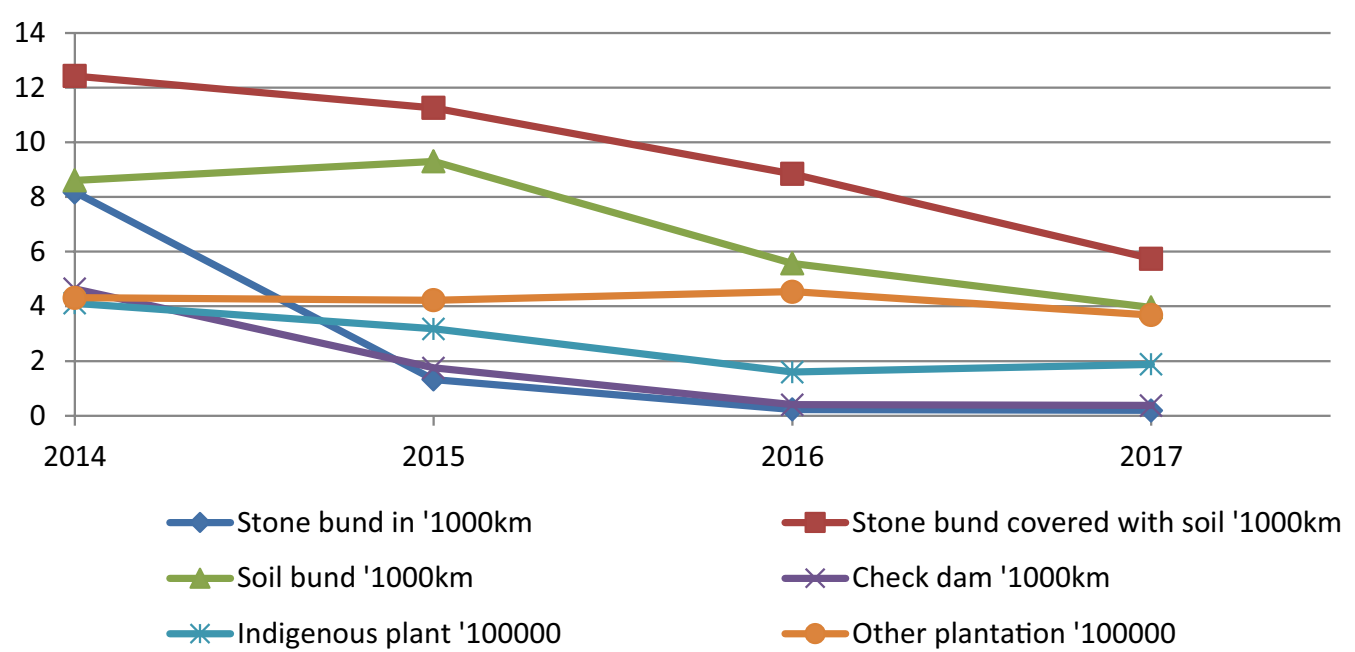

Fig. 2 Soil and water conservation works for the last four years. It shows the decreasing trend of the construction of new SWC practices. It is computed from South Gondar Zone Agriculture Bureau [52]

reaction, property right has an important role in shaping and managing the resources through properly defining the rights of stakeholders [42]. However, the communal lands had no properly defined security of tenure. In other studies, from all types of SWC methods, biological structures were found to be more sustained than the mechanical structures [8]. Through the support of Amhara Forest Enterprise, guards were employed for protected areas. However, when the guard is off site, people release animals for grazing and cut trees immediately. The problem worsens after the crop harvesting as there is shortage of fodder. The other problem is the rigidity of implementation plan. The action plan is directly sent from Woreda, and development units have limited mandate to modify it. Usually, the action plan overlaps with farmers' irrigation and plowing time. Some farmers resist structures/ stone bund/that it consumed farmland, obstacle for plowing, collects harmful insects and reptiles. Thus, farmers till very close to both sides of the structure.

Most of the lowland areas build water harvesting using geomembrane. Water harvesting is not sustained as geomembrane is stolen and misused for home roofing. This is because it has not brought benefit for them and some others do not have good awareness for it. Moreover, water harvesting is challenging as it requires timely collection of water, construction of quality ponds, labor and land. The other challenge is the presence of inconsistent mode of implementing the code of conduct.

FGD discussant farmers explained that:

Our village is named as Metafet Amba. We have our code of conduct and published cash collection receipt. We have public forest named Alem saga and sheleko medhanialem. Owners are punished 30 Birr/cattle if found in the preserved communal land. Farmers also mentioned that local watershed penalty for illegal entrance of livestock on closures varies from place to place; in some areas it is 30 and in others 100 Birr per livestock. Farmers found it feasible to release their animals to the forest/communal land and pay the penalty. However, the problem is those committee member relatives are not properly penalized as of the other community. The worst degraded watershed is selected for conservation work and the remaining worked through revolving system. Complains are common on the watershed selection committee as the remaining watershed farmers demand to have conservation work in their area in the same year. Communal forests are being transferred for Amhara forest enterprise and the sustainability is in question for the fact that farmers thought that its former benefit might be quitted and transferred to the enterprise. The working time of structures is during sunny hours of the day and is very harsh. Farming community has free grazing culture after harvesting period. This had resulted severe destruction of the SWC structures. We are bored of annual maintenance of the same structure. Due to lack of follow-up, termites attack the tree. On the other hand, because of area closures, the former diminished number of wild animals such as pigeon and zigra had now increased. Our children heard them in history, but now they are observing them.

The other problem mentioned by Woreda DA was aspiration of short-term benefit and open grazing. The Woreda key informant mentioned that: 
The short-term benefit is manifested through various occurrences such as tree cutting. If a farmer is found with axe within the communal forest, he will be punished 100 Birr. When a tree is illegally cut, a charge goes to the justice office. However, the justice organs immediately release criminals and sometimes give delayed responses.

The Woreda office of agriculture replied that immediate release is because of the heavy penalty which is up to 10,000 Birr or 10 years of prison. The contemporary closure lands had limited the previous open grazing, and farmers are complaining on the insufficiency of the fodder. Animals are tied due to lack of alternative communal grazing land. The distributed grass from the closures and straw is not sufficient for farmers with more livestock. The FGD discussants complained that the closures were promised to provide grass, fire wood, bee keeping, etc. However, it was not fully realized, and the local farming community is not well motivated to protect these closures. The researcher tried to further grasp the problem by asking the Woreda offices of agriculture. The offices admit the existence of the problem and are providing some alternative options. These options include encourage saving crop residues during crop harvesting, planting grass strips along with the structure works and cut and carry from closures. However, the problem persists across all villages. Thus, the sustainability of closures, forest area communal soil and water conservation works is being challenged by open grazing.

Generally, the sustainability status of the structures from the perspective of official reports diverges from farm households. Official reports firmly mentioned the complete success of the structures mentioning the number of kilometers constructed and the amount of resources committed as their evidence. However, it overlooks how it reduces the problem of land degradation and challenge of climate variability. The farmer was asked what he himself and his neighbor perceive about the future prospect of the structures. This triangulation of the farmers with each other brought contradictory finding. The view of neighbors was pessimist over the sustainability and importance of the structures. Generally, the overall status of the structures falls on the category of sustained but at risk. This was justified with lack of farmers' awareness on the long-term importance of structures; structures consumed farmland, collects harmful reptiles and rats, and its tiresome labor demand.

\section{Conclusion and policy implications}

The research examines the social, economic, environmental, technical and institutional sustainability of community-based SWC practices using analytic hierarchal process. The finding portrayed that all dimensions except economic were sustained but at risk. In terms of the importance of the communitymobilized SWC works, results found to be inconsistent. About $75 \%$ of the farmers proposed the continuation of the structures, but this was completely reversed when farmers were asked about the view of their neighbors' using a triangulation. In this regard, about $86 \%$ of their neighbors' view is to quit the future work of structures. This was justified with labor requirement, high opportunity cost (off-farm employment) and limited direct short-term benefit. The sustainability of the communal lands/closures is being challenged by its insignificant benefit, open grazing, lack of awareness, inadequate follow-up, lack of periodic maintenance, inappropriate structure to the topography and unclear security of tenure. The government has more focused on the mechanical measures of SWC and lack to properly protect and strengthen the biological works. As a result, the community-based climate smart practices lack to properly address land degradation and climate challenges. Most of the structures built on the individual farm land are more properly conserved as compared to the communal/closure-built structures. Landless farmers are dissatisfied by the lack of direct benefit from SWC campaign participation. The nature of conservation works requires community participation in all stages of planning, implementation and evaluation. Except the implementation, the local community had minimal participation in planning, monitoring and evaluation of the structure works. The following three key policy implications are drawn from the finding. Firstly, sustaining the structures requires direct participation of the farmers from planning to monitoring and evaluation. This can be achieved through the application of bottom-up and top to down approaches within the hierarchically established institutional arrangements from Woreda to village. Secondly, the basic reason farmers destroy the SWC structures are that they think the structures are home to rodents and also consumed their farming plots. Thus, accessing mechanisms (for instance access of environment friendly pesticides) for controlling unnecessary rodents is important to eradicate the hesitation of farmers on the structures. Structures require some time to benefit farmers. Sustainability of practices and reduction of opportunity costs can be partly ensured by combining long-term benefits with shortterm benefiting practices. For instance, closures can maximize benefit of the local community by improving the grass cover/fodder, diversified plantation, fruits, etc. Moreover, the farming community should be aware and strengthened by bylaws for sustaining the structures 
and closures. This has the possibility of reducing unauthorized grazing, cutting of trees, etc.

\section{Authors' contributions}

TA designed the study and data collection instruments, carried out the data collection and analyzed the data, and wrote the manuscript. BS and GA participated in the study design, shaped the data collection instruments, coordinated the entire data collection process, technically supported the data analysis process and revised draft the manuscript. All authors read and approved the final manuscript.

\section{Author details}

${ }^{1}$ Center for Environment and Development Studies, College of Development Studies, Addis Ababa University, Addis Ababa, Ethiopia. ${ }^{2}$ Department of Economics, Trent University, Peterborough, Ontario, Canada.

\section{Acknowledgements}

This work was funded by Ethiopian Ministry of Education (Addis Ababa University and Aksum University), Ethiopia. The authors would like to thank local village administrators, data collectors, development agents and the farmers that facilitate and provide the data.

\section{Competing interests}

The authors declare that they have no competing interests.

\section{Availability of data and materials}

Data sharing is not applicable to this article, for no datasets were generated or created during the current study.

\section{Consent for publication}

Not applicable.

\section{Ethics approval and consent to participate}

Not applicable.

\section{Funding}

The authors would like to thank Addis Ababa University and Aksum University for providing financial support for data collection and writing of this study.

\section{Publisher's Note}

Springer Nature remains neutral with regard to jurisdictional claims in published maps and institutional affiliations.

Received: 16 May 2018 Accepted: 19 July 2018

Published online: 13 August 2018

\section{References}

1. Agricultural Transformation Agency. Annual Report Transforming Agriculture in Ethiopia 2013/14, Addis Ababa, Ethiopia, Unpublished. 2014.

2. Agricultural Transformation Agency. Agricultural transformation agenda Progress report covering 2011-2015 in the GTP1 period, Addis Ababa, Ethiopia; unpublished. 2015.

3. World Bank. Ethiopia: managing water resources to maximize sustainable growth. 2006

4. Zeleke G, Bewket W, Alemu D. Economics of adaptation to climate change: ethiopia case study: learning from past experiences with extreme climate events. Unpublished report, 2010.

5. Yesuf M, Di Falco S, Deressa T, Ringler C, Kohlin G. The impact of climate change and adaptation on food production in low-income countries: evidence from the Nile Basin, Ethiopia. Intl Food Policy Res Inst; 2008.

6. Bewket W, Alemu D. Farmers' perceptions of climate change and its agricultural impacts in the Abay and Baro-Akobo River Basins, Ethiopia. Ethiop J Dev Res. 2011;33(1):1-28.

7. Di Falco S, Veronesi M, Yesuf M. Does adaptation to climate change provide food security? A micro-perspective from Ethiopia. Am J Agr Econ. 2011;93(3):829-46.
8. Hunegnaw AT, Tegegnework GM, Dagmawi L, Abiot M, Esubalew T. Sustainability of climate resilient soil and water conservation strategies nexus the practices in tragedy at the upper blue Nile basin of northwestern Ethiopia: economic welfare implication to the farming communities. J Earth Sci Clim Change. 2017;8:399. https://doi.org/10.4172/21577617.1000399.

9. FAO. Climate-smart agriculture and resource tenure in sub-Saharan Africa: a conceptual framework, 2014.

10. Daniel D. Soil and water conservation manual: quideline for Ethiopia. Soil and Water Conservation Team, Natural Resources Management and Regulatory Department, Ministry of Agriculture, Addis Ababa. 2001.

11. Tamene L, Park SJ, Dikau R, Vlek PL. Reservoir siltation in the semi-arid highlands of northern Ethiopia: sediment yield-catchment area relationship and a semi-quantitative approach for predicting sediment yield. Earth Surf Proc Land. 2006;31(11):1364-83.

12. Wolka K, Negash M. Farmers' adoption of soil and water conservation technology: a case study of the Bokole and Toni sub-watersheds, southern Ethiopia. J Sci Dev. 2014;2(1):35-48.

13. Bekele W, Drake L. Soil and water conservation decision behavior of subsistence farmers in the Eastern Highlands of Ethiopia: a case study of the Hunde-Lafto area. Ecol Econ. 2003;46(3):437-51.

14. Tarekegn TH. Two-dimensional hydrodynamic modelling of flooding, using ASTER DEM in ribb catchment, Ethiopia. ITC. 2009.

15. Nkonya E. Soil conservation practices and non-agricultural land use in the south western highlands of Uganda. The International Food Policy Research Institute (IFPRI). 2002;17:2033.

16. Zizinga A, Tenywa MM, Majaliwa JG, Mugarura M, Ababo P, Achom A, Gabiri G, Bamutaze Y, Kizza L, Adipala E. Potential climate change adaptation and coping practices for agricultural productivity in the mountain areas of South Western Uganda. J Sci Res Rep. 2015;7:23-41.

17. Demeke AB. Factors influencing the adoption of soil conservation practices in Northwestern Ethiopia. Discussion Papers (Germany). 2003.

18. Engdawork A, Bork HR. Long-term indigenous soil conservation technology in the Chencha Area, Southern Ethiopia: origin, characteristics, and sustainability. Ambio. 2014:43(7):932-42.

19. Tegene B. Farmers' perceptions of erosion hazards and attitudes towards soil conservation in Gunono, Wolayita, southern Ethiopia. Ethiop J Dev Res. 1992;14(2):31-58.

20. Hagos F. Land degradation and strategies for sustainable land management in the Ethiopian highlands: Tigray region. ILRI (aka ILCA and ILRAD); 2002.

21. Birhanu A, Meseret D. Structural soil and water conservation practices in Farta District, North Western Ethiopia: an investigation on factors influencing continued use. Sci Technol Arts Res J. 2013;2(4):114-21.

22. Gessesse D, Gizaw AK, Hurni H. Assessment of soil erosion and soil conservation practices in Angereb watershed, Ethiopia: technological and land user context. Biophysical and socio-economic frame conditions for the sustainable management of natural resources: Book of abstracts. 2009;52.

23. Kassie M, Zikhali P, Pender J, Köhlin G. Sustainable agricultural practices and agricultural productivity in Ethiopia: does agroecology matter?. rapport nr.: Working Papers in Economics 406. 2009.

24. Simane B, Zaitchik BF. The sustainability of community-based adaptation projects in the Blue Nile Highlands of Ethiopia. Sustainability. 2014;6(7):4308-25.

25. Water Works Design and Supervision Enterprise (WWDSE) and TAHAL Consulting Engineers. Lake Tana Sub-basin four Dams Project, Final feasibility report for Rib dam Project, vol. 8: Watershed Management Study Report. 2008.

26. Ministry of Water, Irrigation and Electricity. Ethiopian Nile Irrigation and Drainage Project, Rib Reservoir Scheme, Resettlement Action Plan, Final Report. 2014

27. Ministry of Agriculture. Agroecological zonations of Ethiopia. Ethiopia: Addis Ababa; 2000.

28. Setegn SG, Srinivasan R, Dargahi B. Hydrological Modelling in the Lake Tana Basin, Ethiopia using SWAT model. Open Hydrol J. 2008;2:49-62.

29. Ministry of Water, Irrigation and Electricity. Land use of Abay basin, Ethiopia, unpublished. 2016.

30. Central Statistics Agency of Ethiopia. Population Projection of Ethiopia for All Regions at Wereda Level from 2014-2017. Ethiopia: Addis Ababa; 2013. 
31. Kothari CR. Research methodology: Methods and techniques. New Age International; 2004

32. Colson G, De Bruyn C. Models and methods in multiple objectives decision making. Math Comput Modelling. 1989;12(10/11):1201-11.

33. Triantaphyllou E. Multi-criteria decision making methods: a comparative study. Sspringer-Science + Business Media B.V.,2000.

34. Belton V, Gear T. On a short-coming of Saaty's method of analytic hierarchies. Omega. 1983;11(3):228-30.

35. Taslicali K, Ercan S. The analytic hierarchy \& the analytic network processes in multicriteria decision making: a comparative study. J Aeronaut Space Technol. 2006; II(4):55-65.

36. Saaty TL. Decision making in complex environments: the analytic network process for decision making with dependence and feedback. Creative Decision Foundation (CDF). 2001;4922.

37. Terrados J, Almonacid G, Pérez-Higueras P. Proposal for a combined methodology for renewable energy planning. Application to a Spanish region. Renew Sustain Energy Rev. 2009;13:2022-30.

38. Saaty TL. Decision making for leaders: the analytic hierarchy process for decisions in a complex world. 3rd ed. Pittsburgh: RWS Publications; 2012.

39. Saaty TL. The analytical hierarchy process. New York: McGraw-Hill; 1980.

40. Alonso J, Lamata T. Consistency in the analytic hierarchy process: a new approach. Int J Uncertain Fuzziness Knowl Based Syst. 2006;14(4):445-59.

41. Wolfslehner B, Vacik H, Lexer MJ. Application of the analytic network process in multi-criteria analysis of sustainable forest management. For Ecol Manage. 2005;207(1-2):157-70.

42. Admassie Y. Twenty years to nowhere. Property rights, land management and conservation in Ethiopia. 1995.

43. Gliessman SR, editor. Agroecosystem sustainability: developing practical strategies. CRC Press; 2000.
44. Wood A. Natural resource management and rural development in Ethiopia. Ethiopia: rural development options. 1990:187-95.

45. Oakley P. Projects with people: The practice of participation in rural development. International Labour Organization; 1991.

46. Tesfaye G, Debebe W. Farmers' perceptions' and participation on mechanical soil and water conservation techniques in Kembata Tembaro Zone: the case of Kachabirra Woreda. Int J Adv Struct Geotech Eng. 2013;2(4):118-31.

47. Gebremedhin Y. Community participation and sustainable soil and water conservation management: the case of Zala-Daget project: Dogu'a Tembien Woreda_-Tigray Highlands, A masters thesis, Addis Ababa University. 2004.

48. Awortwi N. The riddle of community development: factors influencing organisation, participation and self-management in 29 African and Latin American communities. ISS Working papers-General Series. Jan 1, 1999.

49. Biratu AA, Asmamaw DK. Farmers' perception of soil erosion and participation in soil and water conservation activities in the Gusha Temela watershed, Arsi, Ethiopia. Int J River Basin Manage. 2016;14(3):329-36.

50. Dawit T. Impacts And Impediments Of Community Participation On Soil \& Water Conservation To Sustainable Land Resource Management In Laelay Machew Wereda, Tigray, Ethiopia, A Masters Theses, Addis Ababa University. 2014.

51. Tiffen M, Mortimore M, Gichuki F. More people, less erosion: environmental recovery in Kenya. Wiley; 1994.

52. South Gondar Zone Agriculture Bureau. Strategic plan document report of 2010/11-2014/15, unpublished. 2016

Ready to submit your research? Choose BMC and benefit from:

- fast, convenient online submission

- thorough peer review by experienced researchers in your field

- rapid publication on acceptance

- support for research data, including large and complex data types

- gold Open Access which fosters wider collaboration and increased citations

- maximum visibility for your research: over $100 \mathrm{M}$ website views per year

At $\mathrm{BMC}$, research is always in progress.

Learn more biomedcentral.com/submissions 